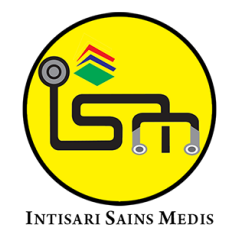

Published by Intisari Sains Medis

\section{Physical activity and vasomotor symptoms in perimenopausal women at Wukirsari Village, Yogyakarta, Indonesia}

\author{
Iwi Liesdiyanata ${ }^{1}$, Dicky Moch Rizal ${ }^{2 *}$, Djaswadi Dasuki ${ }^{3}$
}

\begin{abstract}
${ }^{1}$ Post Graduate Student, Faculty of Medicine, Public Health, and Nursing, Universitas Gadjah Mada, Yogyakarta, Indonesia;

${ }^{2}$ Department of Physiology, Faculty of Medicine, Public Health, and Nursing, Universitas Gadjah Mada, Yogyakarta, Indonesia;

${ }^{3}$ Department of Obstetrics and Gynecology, Faculty of Medicine, Public Health, and Nursing, Universitas Gadjah Mada, Yogyakarta, Indonesia;
\end{abstract}

\section{*Corresponding author: \\ Dicky Moch Rizal; \\ Department of Physiology, Faculty of Medicine, \\ Public Health, and Nursing, Universitas Gadjah \\ Mada, Yogyakarta, Indonesia; \\ drdickyandrologi@ugm.ac.id}

Received: 2021-09-24

Accepted: 2021-11-30

Published: 2021-12-14

\section{ABSTRACT}

Background: Menopause is an event that marks the end of the reproductive phase of a woman. Vasomotor symptoms are one of the primary symptoms of menopausal women and affect about 40-60\% of perimenopausal women. This research aims to investigate the relationship of physical activity with vasomotor symptoms in perimenopausal women.

Methods: The population in this study were 173 women aged 45-54 years who are still experiencing menstruation in the Wukirsari village working area of Puskesmas Cangkringan Sleman-Yogyakarta. The instrument for measuring vasomotor symptoms adopted two questions from the menopause rating scale (hot flushes and night sweats) questionnaire while measuring physical activity using a questionnaire from Riskesdas. Data were analyzed using SPSS version

23 for Windows.

Results: Most of the participants were in the 4550 years age group $(75.73 \%)$, followed by severe vasomotor symptoms $(95.95 \%)$, sufficient physical activity (91.91\%), medium level education (49.71\%), and informal occupation (94.80\%). In addition, this study found that most of the participants were normal Body Mass Index (BMI) (54.34\%), passive smoking (64.74\%), and pre-hypertension (46.20\%). There was a significant relationship between physical activities and BMI to the vasomotor symptoms among women of perimenopausal age $(p<0.05)$.

Conclusion: There was a significant relationship between physical activities and BMI the vasomotor symptoms among women of perimenopausal age.

Keywords: Physical Activity, Vasomotor Symptoms, Body Mass Index, Perimenopause, Blood Pressure, Smoking. Cite This Article: Liesdiyanata, I., Rizal, D.M., Dasuki, D. 2021. Physical activity and vasomotor symptoms in perimenopausal women at Wukirsari Village, Yogyakarta, Indonesia. Intisari Sains Medis 12(3): 876-879. D0l: 10.15562/ism.v12i3.1150

\section{INTRODUCTION}

Every woman underwent three stages in the climacteric period, which were menopause, perimenopause, and postmenopause. The stage in which women underwent menstrual change till the stop of the menstruation and the hormonal change was referred to as perimenopause or the menopause transition period. ${ }^{1}$ Woman at the perimenopause stage underwent secretion of luteinizing hormone (LH) and folliclestimulating hormone (FSH) that could accelerate follicle depletion that caused the decrease in estrogen and inhibin hormone secretion. ${ }^{2}$ According to Survei Demografi dan Kesehatan Indonesia (SDKI), a survey on Indonesian demography and health, menopause is defined as the proportion of women of 30 years of age or more who are not in parturition period, pregnancy, and do not get any menstruation in $\geq 6$ months before the surveyor has not undergone any menstruation. ${ }^{3}$

The SDKI data in 2012 showed that women's life expectancy was 62 years in 1990 and increased to 73 years in $2010 .^{3}$ The life expectancy in the Special District of Yogyakarta was relatively higher than that in other provinces in Indonesia, which was 73.71 years. Women's life expectancy was 75.53 years and higher than that of men (71.78 years). ${ }^{3}$ Additionally, the demographic structure of the special district tended to be an old demographic structure with an increasing number of elderly people, especially women. The longest life expectancy took place in the Sleman regency, which was 75.79 years and the women's life expectancy of the regency was 77.41 , while the mean life expectancy was 73.81 years. ${ }^{4}$

The majority of women $(75.00 \%)$ had vasomotor complaints, including somatic, psychological, and sexual symptoms. The duration of the vasomotor complaint was 4-5 years, but it might also be longer than 10 years after menopause and even for the rest of life. ${ }^{5}$ Perimenopause was the term that covered several years before and after menopause. Women in the perimenopause period underwent irregular menstruation, had vasomotor complaints such as hot flushes and night sweats, and lasted for about 5 to 10 minutes. ${ }^{6}$

One of the efforts to alleviate the menopause symptoms were hormonal therapy, but it had a negative side effect. Umland EM suggested that women who got hormone substitution therapy are at risk of breast cancer, endometrium cancer, stroke, and venous thromboembolism. ${ }^{1}$ 
It was, therefore, necessary to find alternatives in alleviating the menopause symptoms by actively doing physical exercises. A previous study by Kim MJ et al. suggested that regular physical activities could alleviate menopause symptoms. ${ }^{7}$ Therefore, the researcher was interested in studying the correlation between physical exercises and vasomotor symptoms among perimenopausal women. ${ }^{7}$ Based on those mentioned above, this study aims to evaluate the physical activity and vasomotor symptoms in perimenopausal women at Wukirsari Village, Yogyakarta, Indonesia.

\section{MATERIALS AND METHODS}

The study used a cross-sectional design and a quantitative approach conducted at Wukirsari Village in the coverage area of Cangkringan Public Health Services, a local government clinic, in Sleman regency of the Special District of Yogyakarta from August 2016-February 2017. The independent variables of the study were physical exercises, while the external variables were vasomotor symptoms and the external variables were education, occupation, Body Mass Index (BMI), passive smoking, and blood pressure. The study subjects who met the inclusion criteria were women of 45-55 years of age and not in the menopause period and willing to serve as the subjects of the study by signing the informed consent. Meanwhile, the exclusion criteria were women who had undergone or were getting hormone substitution therapy. The sampling technique used in this study were nonprobability sampling and accidental sampling methods among 173 respondents.

The data collecting instruments to measure the variables in the study were adopted from LPKGM UGM/FK regarding the questions of mothers' identity, including education level and occupation. ${ }^{8}$ The instruments to measure the vasomotor symptoms of the women of 45-55 years of age were adopted from the questionnaire of menopause rating scale containing two questions of hot flushes and night sweats. ${ }^{9}$ The questionnaire to measure physical exercises was Riskesdas. ${ }^{10}$ Before the questions of the physical exercises were asked, the respondents were asked to think about all kinds of physical activity that they did continuously for 10 minutes or more. Statistical analysis was carried out using Statistical Package for the Social Sciences (SPSS) for Windows, version 23.0 (SPSS, Inc., Chicago, IL, USA).

\section{RESULTS}

Most of the participants were in the 4550 years age group $(75.73 \%)$, followed by severe vasomotor symptoms (95.95\%), sufficient physical activity (91.91\%), medium level education (49.71\%), and informal occupation (94.80\%) (Table 1). In addition, this study found that most of the participants were normal BMI (54.34\%), passive smoking (64.74\%), and pre-hypertension (46.20\%) (Table 1).

The bivariate analysis results showed that there was a statistically significant correlation between physical activity and vasomotor symptoms $(\mathrm{p}=0.04)$. The women in the overweight category of the body mass index had a significantly twice bigger risk of having vasomotor symptoms than those with normal body mass index $(p=0.03)$ (Table 2). The education, occupation, passive smoking, and blood pressure were statistically not correlated to the vasomotor symptoms ( $p>0.05)$. The women with formal occupation (both civil servants and private employees) had almost 3 times bigger risk of having vasomotor symptoms as compared to those with informal occupations (housewives, farmers, and laborers), although statistically not significant ( $p>0.05$ ) (Table 2).

The women exposed to cigarette smoke indoor cigarette smoke, both daily and occasionally, had a 1.34 times bigger risk than those who were never exposed to indoor cigarette smoke, although not statistically significant ( $p>0.05 ; 95 \% \mathrm{CI}$ : 0.97-1.85). The women with hypertension had a 1.80 times bigger risk of having vasomotor symptoms as compared to those with normal blood pressure ( $\mathrm{p}>0.05$; 95\%CI: 0.97-3.43) (Table 2).

\section{DISCUSSION}

In general, the study has managed to examine the correlation between physical activity and vasomotor symptoms. The

Table 1. Characteristics of respondents.

\begin{tabular}{|c|c|c|}
\hline Variable & $\mathrm{N}=173$ & Percentage \\
\hline \multicolumn{3}{|l|}{ Age (Years) } \\
\hline $45-50$ & 131 & 75.73 \\
\hline $51-55$ & 42 & 24.27 \\
\hline \multicolumn{3}{|l|}{ Vasomotor symptoms } \\
\hline Mild & 7 & 4.05 \\
\hline Severe & 166 & 95.95 \\
\hline \multicolumn{3}{|l|}{ Physical activity } \\
\hline Less & 14 & 8.09 \\
\hline Sufficient & 159 & 91.91 \\
\hline \multicolumn{3}{|l|}{ Education } \\
\hline Basic & 76 & 43.93 \\
\hline Medium & 86 & 49.71 \\
\hline High & 11 & 6.36 \\
\hline \multicolumn{3}{|l|}{ Occupation } \\
\hline Formal & 9 & 5.20 \\
\hline Informal & 164 & 94.80 \\
\hline \multicolumn{3}{|l|}{ BMI $\left(\mathrm{kg} / \mathrm{m}^{2}\right)$} \\
\hline Overweight $(\geq 25)$ & 79 & 45.66 \\
\hline Normal $(<25)$ & 94 & 54.34 \\
\hline \multicolumn{3}{|l|}{ Passive smoking } \\
\hline Yes & 112 & 64.74 \\
\hline No & 61 & 35.26 \\
\hline \multicolumn{3}{|l|}{ Blood Pressure ${ }^{a}$} \\
\hline Hypertension & 40 & 23.10 \\
\hline Pre-Hypertension & 80 & 46.20 \\
\hline Normal & 53 & 30.70 \\
\hline
\end{tabular}

${ }^{\mathrm{a}}$ Hypertension: $\geq 140 / 90 \mathrm{mmHg}$; Pre-Hypertension: 120-139 and/or 80-89 $\mathrm{mmHg}$; Normal: $\leq$ $120 / 80 \mathrm{mmHg}$ 
Table 2. The relationship between physical activity, education, occupation, body mass index, passive smoking, blood pressure with vasomotor symptoms.

\begin{tabular}{|c|c|c|c|c|c|c|}
\hline \multirow{3}{*}{ Variable } & \multicolumn{4}{|c|}{ Vasomotor symptoms } & \multirow{3}{*}{$\begin{array}{c}\text { Crude PR } \\
(95 \% \mathrm{CI})\end{array}$} & \multirow{3}{*}{$\mathbf{p}$} \\
\hline & \multicolumn{2}{|c|}{ Mild } & \multicolumn{2}{|c|}{ Severe } & & \\
\hline & $\mathbf{n}$ & $\%$ & $\mathbf{n}$ & $\%$ & & \\
\hline \multicolumn{7}{|l|}{ Physical activity } \\
\hline Less & 2 & 14.29 & 12 & 85.71 & $3.95(1.09-14.38)^{*}$ & $0.04^{*}$ \\
\hline Sufficient & 5 & 3.14 & 154 & 96.86 & 1 & \\
\hline \multicolumn{7}{|l|}{ Education } \\
\hline Basic & 5 & 6.58 & 71 & 93.42 & $1.15(1.06-1.26)$ & $>0.05$ \\
\hline Medium & 2 & 2.33 & 84 & 97.67 & $1.13(1.05-1.22)$ & \\
\hline High & 0 & 0.00 & 11 & 100.00 & 1 & \\
\hline \multicolumn{7}{|l|}{ Occupation } \\
\hline Formal & 1 & 11.11 & 8 & 88.89 & $2.96(0.43-20.55)$ & $>0.05$ \\
\hline Informal & 6 & 3.66 & 158 & 96.34 & 1 & \\
\hline \multicolumn{7}{|l|}{$\operatorname{BMI}\left(\mathrm{kg} / \mathrm{m}^{2}\right)$} \\
\hline Overweight & 6 & 7.59 & 73 & 92.41 & $1.95(1.38-2.76)^{*}$ & $0.03^{\star}$ \\
\hline Normal & 1 & 1.06 & 93 & 98.94 & 1 & \\
\hline \multicolumn{7}{|l|}{ Passive smoking } \\
\hline Yes & 6 & 5.36 & 106 & 94.64 & $1.34(0.97-1.85)$ & \\
\hline No & 1 & 1.64 & 60 & 98.36 & 1 & \\
\hline \multicolumn{7}{|l|}{ Blood Pressure } \\
\hline Hypertension & 3 & 7.5 & 37 & 92.5 & $1.80(0.97-3.43)$ & $>0.05$ \\
\hline Pre-Hypertension & 3 & 3.7 & 77 & 96.3 & $1.25(0.70-2.25)$ & \\
\hline Normal & 1 & 1.9 & 52 & 98.1 & 1 & \\
\hline
\end{tabular}

${ }^{*}$ Statistically significant if p-value less than 0.05; PR: Prevalence Ratio; CI: Confidence Interval; ${ }^{a} H y p e r t e n s i o n: ~ \geq 140 / 90$ mmHg; Pre-Hypertension: 120-139 and/or 80-89 mmHg; Normal: $\leq 120 / 80 \mathrm{mmHg}$

variables' analysis showed a statistically significant difference between physical activity and vasomotor symptoms ( $\mathrm{p}=0.04)$, meaning that doing sufficient physical activity could alleviate the vasomotor symptoms among women 45-55 years of age. It was consistent with the previous studies result suggesting that physical activities could alleviate menopause symptoms and significantly impact hot flushes. ${ }^{11,12}$

The perimenopause or the menopause transition period that lasted at the ages of 45-55 was when hormonal and menstrual changes occurred. ${ }^{6,13}$ In this period, the secretion of the LH and the FSH increased, causing the depletion of follicles and, in turn, the decrease in the synthesis and secretion of estrogen and inhibin (one of the protein hormones). Many researchers suggested that the primary causal factor of the hot flushes (vasomotor complaint) was the change in the estrogen hormone. ${ }^{13}$ It was also proven in many studies showing that estrogen hormone therapy could alleviate vasomotor symptoms (hot flush). ${ }^{2}$

The education level was statistically not correlated to the vasomotor symptoms. Also, the occupations of the respondents were statistically not correlated to the vasomotor symptoms. The study results showed that there were more vasomotor symptoms found among the women with the informal occupational status (housewives, farmers, and entrepreneurs) compared to those with formal occupational status (civil servants/private employees). ${ }^{1,13}$ It was corroborated by the study results by Shobeiri F et al., showing that there were fewer working women reporting the vasomotor symptoms than the housewives. ${ }^{14}$

Based on the bivariable analysis, the body mass index was statistically correlated to the vasomotor symptoms. It was consistent with the results of the previous studies which also described that women with high body mass index more frequently reported the symptoms of hot flushes than those with normal body mass index. ${ }^{15,16}$ Among middle-aged women, high body mass index was correlated to the change in the menstrual cycle and the symptom of menopause of hot flushes.
Body size expressed in the body mass index represented the important mediator of hormonal content in a woman's body during the menopausal transition. ${ }^{17}$

Being exposed to smoke was statistically not correlated to the vasomotor symptoms but practically correlated. According to Thurston RC and Joffe $\mathrm{H}$, more smoking women reported vasomotor symptoms than those who did not smoke. ${ }^{18}$ Gallicchio L et al., suggested that women who were not active smokers but lived with significant smokers every day experienced hot flushes compared to the women who were not active smokers and did not live along with smokers. ${ }^{19}$ It was because smoking/being exposed to smoke decreased estrogen levels in the body. ${ }^{15}$

The blood pressure was statistically not correlated to the vasomotor symptoms but practically correlated. Meanwhile, according to Sadeghi $\mathrm{M}$ et al., it increased among menopause women. ${ }^{20}$ There were $30-50 \%$ of women who experienced hypertension before 60 years old. It was observed in some symptoms, such 
as aggravating hot flushes. During menopause, insulin resistance increases, and it causes a change in blood pressure, lipid metabolism, and the development of the metabolic syndrome. Additionally, the increase in blood pressure in menopause could increase cardiovascular risk, and it also serves as the predictor of diabetes mellitus type II. ${ }^{21,22}$

The study would become the foundation in the future to repeat the same study in other places. The crosssectional design has proven that there was a correlation between physical activity and vasomotor symptoms. However, the place of the study was a rural area, so that the existing physical exercises were almost homogeneous. Therefore, it was necessary to prove the correlation between physical activities and vasomotor symptoms in urban areas. The vasomotor symptoms in rural areas and those in urban areas might be compared. Therefore, it was necessary to conduct a cross-sectional study in urban areas or a case-control study to determine the difference between the case and the control related to the vasomotor symptoms.

\section{CONCLUSION}

There was a significant relationship between physical activities and BMI to vasomotor symptoms among women of perimenopausal age. The education, occupation, Body Mass Index (BMI), passive smoking, and blood pressure were statistically not correlated to the vasomotor symptoms but practically correlated.

\section{ACKNOWLEDGMENT}

The authors would like to thank all those who offered excellent technical help during the study.

\section{CONFLICT OF INTEREST}

The authors report no conflict of interest regarding the manuscript.

\section{ETHICS CONSIDERATION}

The ethics approval has been obtained from the Medical and Health Research Ethics Committee (MHREC) Faculty of
Medicine, Public Health, and Nursing, Universitas Gadjah Mada, Dr. Sardjito General Hospital, Yogyakarta, Indonesia, with number KE/FK/0365/EC/2017 prior to the study being conducted.

\section{FUNDING STATEMENT}

This research received no specific grant from any funding agency in the public, commercial, or non-profit sectors.

\section{AUTHOR CONTRIBUTIONS}

D.M.R and I.L conceived the presented idea, developed the theory, and performed the computations. D.M.R and D.D verified the analytical methods and encouraged I.L to investigate and supervise the findings of this work. D.M.R and I.L wrote the manuscript with the support of D.D. All authors discussed the results and contributed to the final manuscript.

\section{REFERENCES}

1. Umland EM. Treatment strategies for reducing the burden of menopause-associated vasomotor symptoms. J Manag Care Pharm. 2008;14(3 Suppl):14-19.

2. Whiteman MK, Staropoli CA, Benedict JC, Borgeest C, Flaws JA. Risk factors for hot flashes in midlife women. J Womens Health (Larchmt). 2003;12(5):459-472.

3. Badan Pusat Statistik (BPS). Survei Demografi dan Kesehatan Indonesia Tahun 2012. 2012. [Dapat diakses pada: https://www.bps.go.id/ news/2012/05/28/6/survei-demografi-dankesehatan-indonesia-2012--sdki12-.html].

4. Badan Penelitian dan Pengabdian Masyarakat (BPPM). Data Gender dan Anak Daerah Istimewa Yogyakarta Tahun 2015. 2015. [Dapat diakses pada: https://dp3ap2kb.jogjakota. go.id/].

5. Berin E, Hammar ML, Lindblom H, LindhÅstrand L, Spetz Holm AC. Resistance training for hot flushes in postmenopausal women: Randomized controlled trial protocol. Maturitas. 2016;85:96-103.

6. Santoro N. Perimenopause: From Research to Practice. J Womens Health (Larchmt). 2016;25(4):332-339.

7. Kim MJ, Cho J, Ahn Y, Yim G, Park HY. Association between physical activity and menopausal symptoms in perimenopausal women. BMC Womens Health. 2014;14:122.

8. LPKGM. Surveilans Longitudinal LPKGMFK UGM tahun 2005. Yogyakarta: LPKGM Fakultas Kedokteran Universitas Gadjah Mada (UGM). 2005.

9. Heinemann LA, Potthoff P, Schneider HP. International versions of the Menopause Rating
Scale (MRS). Health Qual Life Outcomes. 2003;1:28

10. Kementerian Kesehatan Republik Indonesia (KEMENKES RI). Kuesioner Kesmas RISKESDAS 2007. Jakarta: KEMENKES RI. 2007.

11. Canário AC, Cabral PU, Spyrides MH, Giraldo PC, Eleutério J Jr, Gonçalves AK. The impact of physical activity on menopausal symptoms in middle-aged women. Int J Gynaecol Obstet. 2012;118(1):34-36.

12. Skrzypulec V, Dabrowska J, Drosdzol A. The influence of physical activity level on climacteric symptoms in menopausal women. Climacteric. 2010;13(4):355-361.

13. McVeigh C. Perimenopause: more than hot flushes and night sweats for some Australian women. J Obstet Gynecol Neonatal Nurs. 2005;34(1):21-27.

14. Shobeiri F, Jenabi E, Hazavehei SM, Roshanaei G. Quality of Life in Postmenopausal Women in Iran: A Population-based Study. J Menopausal Med. 2016;22(1):31-38.

15. Di Donato P, Giulini NA, Bacchi Modena A, Cicchetti G, Comitini G, Gentile G, et al. Factors associated with climacteric symptoms in women around menopause attending menopause clinics in Italy. Maturitas. 2005;52(3-4):181-189.

16. Huang AJ, Subak LL, Wing R, West DS, Hernandez AL, Macer J, et al. An intensive behavioral weight loss intervention and hot flushes in women. Arch Intern Med. 2010;170(13):1161-7.

17. Freeman EW, Sammel MD, Lin H, Gracia CR. Obesity and reproductive hormone levels in the transition to menopause. Menopause. 2010;17(4):718-726.

18. Thurston RC, Joffe H. Vasomotor symptoms and menopause: findings from the Study of Women's Health across the Nation. Obstet Gynecol Clin North Am. 2011;38(3):489-501.

19. Gallicchio L, Miller SR, Visvanathan K, Lewis LM, Babus J, Zacur H, et al. Cigarette smoking, estrogen levels, and hot flashes in midlife women. Maturitas. 2006;53(2):133-43.

20. Sadeghi M, Khalili M, Pourmoghaddas M, Talaei M. The correlation between blood pressure and hot flashes in menopausal women. ARYA Atheroscler. 2012;8(1):32-35.

21. Maas AH, Franke HR. Women's health in menopause with a focus on hypertension. Neth Heart J. 2009;17(2):68-72.

22. Arsani NLKA, Agustini NNM, Wahyuni NPDS. Impaired cognitive function and its relationship with menopausal onset and exercise intensity of elderly women. Bali Medical Journal. 2020;9(2):419-422.

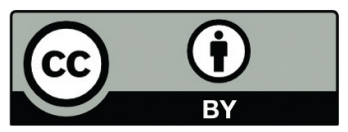

This work is licensed under a Creative Commons Attribution 